\title{
Hubungan antara Tumor Necrosis Factor Alpha dengan Demam Berdarah Dengue
}

\author{
Felix Candra Sutanto, Max F.J. Mantik, Vivekenanda Pateda \\ Bagian Ilmu Kesehatan Anak, Fakultas Kedokteran Universitas Sam Ratulangi / BLU RSUP Prof. Dr. \\ R.D. Kandou, Manado
}

\begin{abstract}
Latar belakang. Sampai saat ini patogenesis demam berdarah dengue (DBD) belum dipahami secara sempurna. Pada kasus DBD didapatkan adanya peningkatan kadar TNF- $\alpha$, sitokin yang poten dalam meningkatkan permeabilitas pembuluh darah. Penelitian sebelumnya mendapatkan adanya peningkatan kadar TNF- $\alpha$ yang bermakna pada DBD.

Tujuan. Mengetahui hubungan antara kadar TNF- $\alpha$ dengan keparahan DBD.

Metode. Penelitian analitik observasional dengan pendekatan potong lintang selama bulan Ju li hingga Desember 2011. Pasien didiagnosis DBD berdasarkan kriteria WHO. Data berupa hemoglobin, hematokrit, jumlah leukosit, jumlah trombosit, dan kadar TNF- $\alpha$ dikumpulkan selama penelitian. Analisis statistik menggunakan korelasi Spearman's Rho dengan tingkat kemaknaan $\mathrm{p}<0,05$.

Hasil. Didapatkan tiga puluh delapan anak, 27 di antaranya didiagnosis DBD tanpa syok dan 11 DBD dengan syok. Rerata usia kelompok DBD tanpa syok adalah 7,56 (SB 3,06) tahun (95\% IK 6,35-8,76 tahun) dan rerata usia kelompok DBD dengan syok adalah 6,82 (SB 3,25) tahun (95\% IK 4,63-9,00 tahun). Rerata kadar TNF- $\alpha$ kelompok DBD tanpa syok adalah 13,13 (SB 7,57) pg/ml (95\% IK 10,14-16,13 pg/ml) dan rerata kadar TNF- $\alpha$ kelompok DBD dengan syok adalah 260,52 (SB 239,08) pg/ml (95\% IK 99,90-421,13 pg/ml). Didapatkan hubungan positif yang bermakna antara kadar TNF $\alpha$ plasma dengan tingkat keparahan/derajat DBD (rs 0,885; $\mathrm{p}<0,001)$.

Kesimpulan. Semakin berat derajat DBD yang terjadi semakin tinggi kadar TNF- $\alpha$

Sari Pediatri 2013;15(4):244-8.
\end{abstract}

Kata kunci: TNF $\alpha$, demam berdarah dengue, anak

\footnotetext{
Alamat korespondensi:

Dr. Felix Candra Sutanto, Sp.A. Bagian Ilmu Kesehatan Anak, Fakultas Kedokteran Universitas Sam Ratulangi-BLU RSUP. Prof. Dr. R.D. Kandou, Manado. Jl. Raya Tanawangko, Manado 95115. P.O. Box 66. Telp. (0431) 821652 ; Fax. (0431) 859091. E-mail : felixc_medz@ yahoo.co.id
}

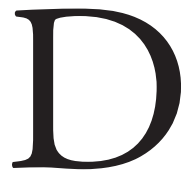
engue merupakan suatu penyakit endemik yang saat ini telah menjangkiti lebih dari seratus negara, baik yang terletak di daerah tropis maupun subtropis. ${ }^{1,2}$ Morbiditas dan mortalitas demam berdarah dengue (DBD) dilaporkan bervariasi dari berbagai negara yang disebabkan oleh beberapa faktor antara lain usia, kepadatan vektor, tingkat penyebaran virus dengue, 
serotipe virus dengue, dan kondisi metereologi. ${ }^{3} \mathrm{Di}$ Indonesia, infeksi virus dengue masih merupakan masalah kesehatan utama dan dapat menyebabkan kejadian luar biasa secara nasional dengan angka mortalitas yang tinggi. ${ }^{4}$

Patofisiologi penting pada infeksi virus dengue yang membedakan DBD dengan demam dengue (DD) adalah peningkatan permeabilitas pembuluh darah yang menyebabkan perembesan plasma. ${ }^{5}$ Patogenesis peningkatan permeabilitas pembuluh darah pada DBD belum diketahui secara pasti, diduga peranan dari sitokin dan mediator kimiawi antara lain tumor necrosis factor alpha (TNF- $\alpha$ ), interleukin-1 (IL-1), komplemen dan histamin. ${ }^{6}$

Penelitian akhir-akhir ini telah menemukan adanya peningkatan dari TNF- $\alpha$ pada DBD.-9 Mengenai hubungan antara TNF- $\alpha$ dengan DBD pada anak masih sedikit dilakukan. Oleh karena itu, perlu dilakukan penelitian untuk mencari hubungan antara TNF- $\alpha$ dengan DBD pada anak, khususnya di wilayah kota Manado sehingga dapat diketahui peran TNF- $\alpha$ pada kasus DBD pada anak dengan harapan menambah wawasan patogenesis DBD agar syok DBD pada anak di Indonesia khususnya di Manado dapat terdeteksi dan ditangani secara dini.

\section{Metode}

Penelitian analitik observasional dengan pendekatan potong lintang pada pasien yang dirawat di bangsal Subbagian Infeksi Tropik Ilmu Kesehatan Anak BLU RSUP Prof. Dr. R.D. Kandou, Manado, antara Juli 2009 sampai dengan Desember 2009 dengan diagnosis DBD. Kriteria diagnosis DBD didasarkan pada kriteria klinis dan kriteria laboratoris dari World Health Organization (WHO) tahun $1997 .{ }^{10}$ Kriteria klinis yang digunakan meliputi demam tinggi mendadak, tanpa sebab jelas dan berlangsung terus-menerus selama 2-7 hari, terdapat manifestasi perdarahan, pembesaran hati, dan syok. Sedangkan kriteria laboratoris yang digunakan yaitu trombositopenia $\left(100.000 / \mathrm{mm}^{3}\right.$ atau kurang) dan hemokonsentrasi (peningkatan hematokrit $20 \%$ atau lebih). Semua pasien yang dicurigai DBD selanjutnya akan dikonfirmasikan dengan pemeriksaan serologis. Demam berdarah dengue derajat I dan II dikelompokkan sebagai DBD tanpa syok, sedangkan DBD derajat III dan IV dikelompokkan sebagai DBD dengan syok. Kriteria inklusi adalah semua anak DBD dengan usia 1-13 tahun serta orang tua menyetujui ikut serta dan bersedia mengisi formulir penelitian. Pasien yang mendapatkan pengobatan dengan kortikosteroid dan yang mendapatkan transfusi darah sebelum dilakukan pemeriksaan akan dieksklusi dari penelitian ini. Analisis data menggunakan analisis deskripsi untuk data karakteristik anak dan data laboratorium, serta analisis koefisien korelasi Spearman's Rho yang diolah dengan program SPSS 20,0 untuk mengetahui apakah ada hubungan antara kadar TNF- $\alpha$ plasma dan derajat/ tingkat keparahan DBD dengan nilai kemaknaan bila $\mathrm{p}<0,05$.

\section{Hasil}

Selama periode penelitian didapatkan jumlah sampel 38 pasien yang memenuhi kriteria inklusi (Tabel 1). Pasien perempuan $(60,5 \%)$ lebih banyak dari laki-laki (39,5\%). Tabel 2 memperlihatkan karakteristik data laboratorium dari semua sampel penelitian. Tertera bahwa rerata kadar TNF- $\alpha$ plasma kelompok DBD dengan syok mempunyai nilai yang lebih tinggi apabila dibandingkan dengan kelompok DBD tanpa syok.

Dihitung dengan Spearman's Rho correlation terbukti bahwa terdapat korelasi positif yang bermakna antara kadar TNF- $\alpha$ plasma dengan derajat/tingkat

Tabel 1. Karakterisitik pasien berdasarkan diagnosis

\begin{tabular}{lcc}
\hline \multirow{2}{*}{ Karakteristik } & \multicolumn{2}{c}{ Diagnosis } \\
\cline { 2 - 3 } & DBD tanpa syok $(\mathrm{n}=27)$ & DBD dengan syok $(\mathrm{n}=11)$ \\
\hline Usia (tahun) & $7,56(3,06)$ & $6,82(3,25)$ \\
Rerata (SB) & $8,00(6,35 ; 8,76)$ & $6,00(4,63 ; 9,00)$ \\
Median (IK 95\%) & 11 & 4 \\
Jenis kelamin & 16 & 7 \\
Laki-laki & & \\
Perempuan & & \\
\hline
\end{tabular}


Felix Candra Sutanto dkk: Hubungan antara tumor necrosis factor alpha dengan DBD

Tabel 2. Karakterisitik data laboratorium berdasarkan diagnosis

\begin{tabular}{|c|c|c|}
\hline \multirow{2}{*}{ Karakteristik } & \multicolumn{2}{|c|}{ Diagnosis } \\
\hline & DBD tanpa syok $(\mathrm{n}=27)$ & DBD dengan syok $(\mathrm{n}=11)$ \\
\hline \multicolumn{3}{|l|}{ Hemoglobin (g/dL) } \\
\hline Rerata (SB) & $13,05(1,22)$ & $14,49(2,38)$ \\
\hline Median (IK 95\%) & $13,30(12,57 ; 13,53)$ & $14,30(12,89 ; 16,09)$ \\
\hline \multicolumn{3}{|l|}{ Hematokrit (\%) } \\
\hline Rerata (SB) & $38,84(3,90)$ & $45,20(6,97)$ \\
\hline Median (IK 95\%) & $39,30(37,30 ; 40,38)$ & $44,00(40,52 ; 49,88)$ \\
\hline \multicolumn{3}{|l|}{ Leukosit $\left(\times 10^{3} / \mathrm{mm}^{3}\right)$} \\
\hline Rerata (SB) & $6,809(3,190)$ & $4,574(1,898)$ \\
\hline Median (IK 95\%) & $6,200(4,666 ; 8,952)$ & $4,400(3,823 ; 5,325)$ \\
\hline \multicolumn{3}{|l|}{ Trombosit $\left(\mathrm{x} 10^{3} / \mathrm{mm}^{3}\right)$} \\
\hline Rerata (SB) & $89,444(49,855)$ & $52,000(41,617)$ \\
\hline Median (IK 95\%) & $82,000(69,722 ; 109,167)$ & $44,000(24,041 ; 79,959)$ \\
\hline \multicolumn{3}{|l|}{ TNF- $\alpha(\mathrm{pg} / \mathrm{mL})$} \\
\hline Rerata (SB) & $13,13(7,57)$ & $260,52(239,08)$ \\
\hline Median (IK 95\%) & $12,10(10,14 ; 16,13)$ & $176,00(99,90 ; 421,13)$ \\
\hline
\end{tabular}

keparahan DBD $\left(r_{s}=0,885 ; p<0,001\right)$. Artinya semakin tinggi kadar TNF- $\alpha$ plasma yang didapatkan maka semakin berat derajat DBD yang ditemukan.

\section{Pembahasan}

Mekanisme kebocoran plasma yang terjadi pada DBD bersifat multifaktorial. Pemahaman patogenesis dari DBD perlu diperhatikan dan dipelajari seluruh faktor yang berperan, baik secara epidemiologis, klinis, imunologis, dan patologis dari virus dengue maupun hospes. ${ }^{11}$ Dilaporkan peningkatan sitokin memiliki potensi untuk meningkatkan permeabilitas vaskular pada DBD. ${ }^{12}$

Demam berdarah dengue mempunyai karakteristik utama berupa kebocoran plasma yang bersifat mendadak dan sementara. Kebocoran plasma pada DBD umumnya berlangsung tidak lebih dari 48 jam dan diikuti oleh proses penyembuhan yang cepat dan sempurna. Hal tersebut mengindikasikan bahwa terdapat perubahan sementara dari faktor-faktor yang mengatur permeabilitas vaskular. ${ }^{13}$ Kurane dan Takasaki ${ }^{14}$ menyatakan bahwa peningkatan sitokin dan mediator kimia secara cepat tampaknya berperan utama menyebabkan kebocoran plasma, syok, dan perdarahan. Basu dan Chaturvedi ${ }^{15}$ mengemukakan bahwa peningkatan permeabilitas vaskular tanpa disertai oleh kelainan morfologi pada DBD disebabkan karena adanya cytokine tsunami yang diakibatkan oleh berbagai patomekanisme.

Nguyen $\mathrm{dkk}^{7}$ dalam penelitian mereka mendapatkan kadar plasma TNF- $\alpha$ pasien DBD lebih tinggi dibandingkan dengan kelompok kontrol. Pada penelitian yang dilakukan oleh Braga EL $\mathrm{dkk}^{8}$ didapatkan peningkatan ekspresi dari TNF- $\alpha$ secara signifikan pasien DBD terutama dengan manifestasi perdarahan. Chakravarti dan Kumaria9 mendapatkan bahwa terdapat peningkatan kadar plasma TNF- $\alpha$ pasien DBD dibandingkan dengan pasien demam dengue sehingga dapat membuktikan bahwa TNF- $\alpha$ mempunyai peran dalam menyebabkan peningkatan permeabilitas kapiler yang menjadi karakteristik utama DBD.

Kami mendapatkan rerata kadar plasma TNF- $\alpha$ DBD tanpa syok 13,13 (SD 7,57) pg/mL (95\% IK 10,14$16,13 \mathrm{pg} / \mathrm{mL}$ ) sedangkan rerata kadar plasma TNF- $\alpha$ pada DBD dengan syok 260,52 (SD 239,08) pg/mL (95\% IK 99,90-421,13 pg/mL). Kadar plasma TNF- $\alpha$ yang didapatkan lebih tinggi apabila dibandingkan dengan penelitian sebelumnya oleh Nguyen $\mathrm{dkk}^{7}$ yang mendapatkan rerata kadar plasma TNF- $\alpha$ 9,0 (SD 13,2) $\mathrm{pg} / \mathrm{mL}$ (95\% IK 0-77,6 pg/mL). Hal tersebut dapat disebabkan oleh perbedaan karakteristik antara kedua sampel penelitian. Sampel penelitian kami adalah usia anak (1-13 tahun) yang terdiri dari pasien DBD tanpa dan dengan syok, dibandingkan dengan penelitian oleh Nguyen dengan sampel usia anak $<12$ bulan. Anak 
memiliki respon imunologi berbeda dari bayi yang mungkin juga memiliki respon TNF- $\alpha$ yang berbeda pula. Selain itu pula, terdapat perbedaan dari instrumen pemeriksaan atau kit yang dipakai untuk memeriksa kadar plasma TNF- $\alpha$ sehingga dapat memberikan nilai yang berbeda pula.

Kami mendapatkan adanya hubungan yang bermakna antara kadar TNF- $\alpha$ plasma dengan derajat/ keparahan DBD. Hasil tersebut menyatakan bahwa semakin tinggi kadar TNF- $\alpha$ semakin berat derajat /keparahan DBD yang terjadi. Syok merupakan manifestasi klinis yang menandakan kebocoran plasma yang berat pada DBD. Hal tersebut menunjukkan bahwa TNF- $\alpha$ berhubungan dengan derajat kebocoran plasma yang terjadi, semakin tinggi kadar TNF- $\alpha$ semakin berat derajat kebocoran plasma yang terjadi sehingga berpotensi untuk menyebabkan terjadinya syok. Sesuai dengan penelitian dari Chakravati dan Kumaria9 yang mendapatkan peningkatan kadar plasma TNF- $\alpha$ yang lebih tinggi pasien DBD dibandingkan dengan pasien DD. Pada DBD telah terjadi kebocoran plasma, berbeda dengan DD yang belum terjadi kebocoran plasma. ${ }^{11}$ Kadar plasma TNF- $\alpha$ yang lebih tinggi pada DBD dibandingkan dengan DD menunjukkan bahwa TNF- $\alpha$ berperan pada proses terjadinya kebocoran plasma.

Peningkatan TNF- $\alpha$ pada DBD diakibatkan oleh dua patomekanisme penting yang diyakini terjadi pada pasien DBD, yaitu tingginya viral load dan aktivasi sejumlah besar sel $\mathrm{T}$ yang menyebabkan terjadinya cytokine tsunami, termasuk TNF- $\alpha .^{11,15}$ Tumor necrosis factor alpha merupakan faktor terlarut yang berperan penting dalam peningkatan permeabilitas vaskular. Peningkatan TNF- $\alpha$ akan menyebabkan peningkatan ekspresi dari ICAM-1, VCAM-1, selectin dan integrin. Adanya interaksi antara ICAM-1 dan $\beta 2$ integrin serta VCAM-1 dan $\beta 1$ integrin akan merangsang granula pada sel darah putih untuk melepaskan molekul HBP/ CAP 37 atau lebih dikenal sebagai azurocidin. Molekul tersebut kemudian akan berikatan dengan reseptor heparin sulfate proteoglycan pada permukaan endotel. Aktivasi dari reseptor heparin sulfate proteoglycan akan menyebabkan perubahan dari sitoskeletal endotel sehingga bentuk endotel akan menyusut dan akan terbentuk celah endotelial. Adanya celah tersebut yang kemudian akan menyebabkan terjadinya kebocoran plasma pada patogenesis DBD. ${ }^{16}$

Keterbatasan dari penelitian potong lintang, pemeriksaan kadar TNF- $\alpha$ hanya dilakukan satu kali pada saat pasien masuk ke rumah sakit walaupun lama sakit yang dialami tidak berbeda (semua dalam fase defervescent). Penelitian tentang hubungan TNF- $\alpha$ dengan DBD yang bersifat prospektif kohort perlu dlakukan. Selain itu, pada DBD, meskipun dikatakan TNF- $\alpha$ adalah sitokin yang berperan penting pada patogenesis DBD, terdapat sitokin dan faktor terlarut lainnya yang bersama-sama secara simultan menyebabkan terjadinya kebocoran plasma.

\section{Kesimpulan}

Penelitian kami memberikan pemahaman yang baru bagi para ilmuwan dan praktisi di bidang kesehatan, khususnya bidang ilmu kesehatan anak. Terutama memberikan tambahan pengetahuan tentang pemahaman terhadap patogenesis dari DBD yang hingga saat ini masih belum dapat dijelaskan secara keseluruhan. Melalui penelitian kami sebagai praktisi kesehatan, peningkatan kadar plasma TNF- $\alpha$ pada pasien DBD dapat memberikan informasi klinis bagi praktisi kesehatan bahwa pasien memiliki kecenderungan untuk mengalami syok.

\section{Daftar pustaka}

1. Halstead SB. Dengue. Lancet 2007;370:1644-52.

2. WHO. Dengue, dengue haemorrhagic fever and dengue shock syndrome in the context of the integrated management of childhood illness. WHO-FCH-CAH; 2005.

3. Soedarmo SP. Masalah demam berdarah di Indonesia. Dalam: Demam berdarah dengue. Jakarta: Balai Penerbit Fakultas Kedokteran Universitas Indonesia; 2005.h.1521.

4. Setiati TE. Faktor hemostasis dan faktor kebocoran vaskuler sebagai faktor diskriminan untuk memprediksi syok pada demam berdarah dengue [disertasi]. Semarang: Universitas Diponegoro; 2004.

5. Hadinegoro SRH, Soegiyanto S, Wuryadi S, Suroso T. Tatalaksana demam berdarah dengue. Jakarta: Departemen Kesehatan RI;2006.h.2-3.

6. Gubler DJ. Dengue and dengue hemorrhagic fever. Clin Microbiol Rev 1998;11:480-96.

7. Nguyen Thanh L, Huan Yao L, Nguyen Trong L, Yee Shin L, Le Bich L, Chiao Feng Y, dkk. Dengue hemorrhagic fever in infants: a study of clinical and cytokine profile. 
J Infect Dis 2004;189:221-32.

8. Braga EL, Moura P, Pinto LM, Ignacio SR, Oliveira MJ, Cordeiro MT, dkk. Detection of circulant tumor necrosis factor-alpha, soluble tumor necrosis factor p75 and infant in brazilian patients with dengue fever and dengue hemorrhagic fever. Mem Inst Oswaldo Cruz 2001;96:229-32.

9. Chakravarti A, Kumaria R. Circulating levels of tumour necrosis factor- $\alpha \&$ interferon- $\gamma$ in patients with dengue $\&$ dengue haemorrhagic fever during an aoutbreak. Indian J Med Res 2005;123-34.

10. Rampengan TH. Demam berdarah dengue pada anak di RSU Manado. MKI 1986;6:300-5.

11. Martina BE, Koraka P, Osterhaus AD. Dengue virus pathogenesis: an integrated review. Clin Microbiol Rev 2009;22:564-81.
12. Chaturvedi UC, Agarwal R, Elbishbishi EA, Mustafa AS. Cytokine cascade in dengue hemorrhagic fever: implications for pathogenesis. Immunol Med Microbiol 2000;28:183-8.

13. Srikiatkhachorn A, Ajariyakhajorn C, Endy TP, Kalayanarooj S, Libraty DH, Green S, dkk. Virusinduced decline in soluble vascular endothelial growth receptor 2 is associated with plasma leakage in dengue hemorrhagic fever. J Virol 2007;81:1592-600.

14. Kurane I, Takasaki T. Dengue fever and dengue haemorrhagic fever: challenges of controlling an enemy still at large. Rev Med Virol 2001;11:301-11.

15. Basu A, Chaturvedi UC. Vascular endothelium: the battlefield of dengue viruses. FEMS Immunol Med Microbiol 2008;53:287-99.

16. Ley K. Plugging the leaks. Nat Med 2001;7:1123-7. 